\title{
Developing Global Competencies through International Teaching: Using Critical Cosmopolitan Theory to Compare Case Studies of Two Study Abroad Programs
}

\author{
Erik Jon Byker \\ University of North Carolina, Charlotte \\ Tingting $X u$ \\ Stephen F. Austin University
}

\begin{abstract}
:
For students to become global citizens they need globally competent teachers. The purpose of this article is to describe and compare the development of global competencies in teacher candidates who participated in international teaching-focused study abroad programs. The article is framed by Critical Cosmopolitan Theory (Byker, 2013), which offers a lens for the development of global competencies through the fusion of critical consciousness (Freire, 1970) and cosmopolitanism (Appiah, 2010). In the field of teacher education, study abroad experiences can help enhance teacher candidates' commitment to culturally responsive teaching practices (Gay, 2002) and intercultural awareness (Hammer, Bennett, \& Wiseman, 2003). The article reports on two case studies of study abroad programs for U.S. teacher candidates. One case study focuses on a study abroad program in China ( $\mathrm{n}=13)$ and the other case study focuses on a study abroad program in South Africa $(\mathrm{n}=22)$. The article compares the teacher candidates' perceptions of their study abroad experiences in relationship to the development of global competencies.
\end{abstract}

\section{Introduction}

Given the impact of globalization and technological innovations on education, teachers face the challenge of preparing global citizens. Educating globally competent citizens requires that teachers be culturally responsive and interculturally competent, and have a strong awareness of international issues. Teachers and schools continue to share a paramount role in preparing today's students to tackle the problems of tomorrow (Byker \& Putman, 2019; Byker \& Thomas, 2018). Elementary schools and teachers, in particular, are at the forefront of the work of preparing citizens who are globally aware and responsive to diversity. This is important work in U.S. schools as about a quarter of children (25\%) under 18 years old have a parent who was not born in the United States (Kandel, 2013). Elementary school classrooms in the United States, especially in urban areas, represent the world's diversity of cultures, ethnicities, and values (Goodwin, 2010; Rong \& Preissle, 2009). We need globally competent teachers — starting at the early childhood and elementary school levelswho have cross-cultural understanding and intercultural awareness (Longview Foundation, 2008). The inclusion of international teaching experiences through study abroad programs has great possibilities for preparing teacher candidates to become globally competent. The purpose of our 
article is to compare two study abroad programs for teacher candidates. In the article, we examine and report on the international teaching and learning experiences of teacher candidates who participated in study abroad programs, which were located in China and South Africa. Additionally, our study includes a comparison of the impact of the study abroad experience on the development of global competencies between the two samples of participating teacher candidates.

\section{Literature Review}

Teacher education programs have an important role in preparing globally competent teachers. Study abroad opportunities can help prepare teacher candidates to become globally competent. Coupled with international teaching and clinical experiences, study abroad immerses teacher candidates in unfamiliar contexts and curricula (Byker, 2019; Byker, Putman, LeGrange, \& Reddy, 2019; Intolubbe-Chmil, Spreen, \& Swap, 2012). The literature shows that study abroad and international teaching experiences have the following effects: improvements in reflection (Kissock \& Richardson, 2010); personal and professional growth (Pence \& Macgillivray, 2008; Willard-Holt, 2001); and greater appreciation for cultural diversity (Byker, Xu, \& Chen, 2016; Byker \& Putman, 2019; Doppen, 2010). Researchers also found that international teaching experiences better equipped teacher candidates in the following ways: culturally sustaining pedagogies (Paris, 2012); experiences for the development of intercultural competency (Longview Foundation, 2008); greater confidence to communicate in new environments (Medina, Hathaway, \& Pilonieta, 2015; Pilonieta, Medina, \& Hathaway, 2017); and increasing social and emotional learning opportunities (Byker, 2019). Doppen and An (2014) found that when teacher education programs couple study abroad with international teaching experiences, they support teacher candidates' identities as global citizen educators. In light of all these positive findings related to study abroad, the literature is still unclear about the impact of study abroad and international teaching opportunities on teacher candidates' perceptions and development of global competencies. Our article addresses this literature gap by examining and comparing two case studies of elementary school teacher-preparation study abroad programs-one in China and the other in South Africa-on the development of global competencies among teacher candidates.

\section{Theoretical Framework}

We frame our study with Critical Cosmopolitan Theory (Byker, 2013). Critical Cosmopolitan Theory maps the Asia Society's Global Competency Matrix (Mansilla \& Jackson, 2011) onto Paulo Freire's (1970, 1994, 1998) notions regarding the development of conscientization or critical consciousness. Critical Cosmopolitan Theory provides a conceptual frame for developing global citizens who are both critically conscious and humane.

Figure 1 shows a graphic representation of Critical Cosmopolitan Theory, which is premised on the understanding that the development of global citizenship includes the movement toward critical consciousness. Indeed, globally competent people are engaged in literacy acts or what Paulo Freire (1970) explains as reading and rewriting the world. Reading the world includes having curiosity and being willing to investigate the world in order to recognize the different perspectives among people and societies. Coincidentally, investigating the world and recognizing perspectives are the first two of the Asia Society's four global competencies. Reading the world includes having eyes opened to the globe's diversity and pluralism, and to social injustices that lead to strife and conflict in many societies (Byker, 2014, 2015, 2017, 2019; Freire, 1998). 
Figure 1. A graphic representation of Critical Cosmopolitan Theory.

\section{Paulo Freire's Concepts}

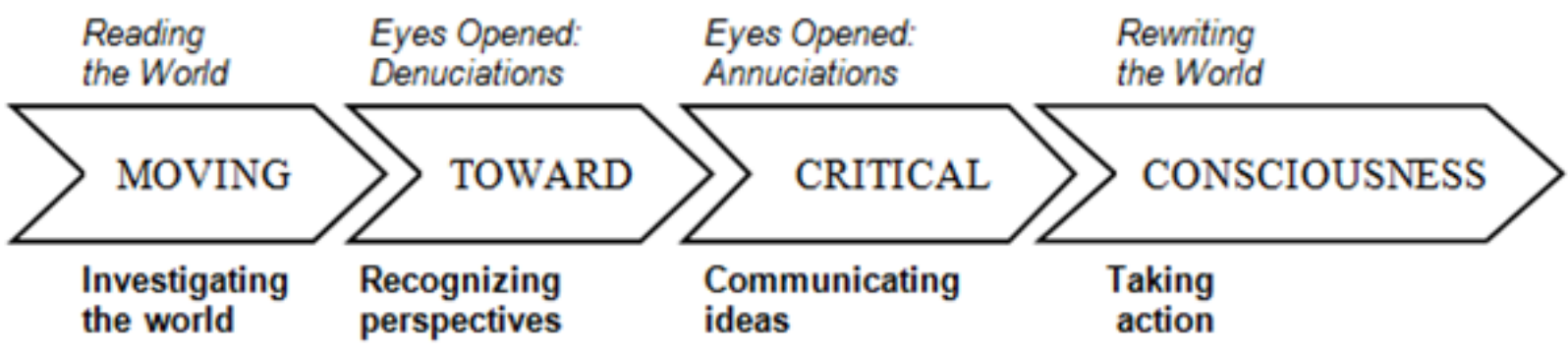

Asia Society's Global Competencies

When eyes are opened to reading the world, learners and teachers are primed to begin rewriting the world through communication and action (Bhattacharjea \& Byker, 2017). Rewriting the world is the conscious engagement in social activities, and aligns to global competencies of communicating ideas and taking action, which are the remaining two of the Asia Society's four global competencies. Critical Cosmopolitan Theory posits that becoming a globally competent person requires acts of reading the world and rewriting the world. The Asia Society organizes these acts into four competencies that are part of the global competency matrix. As explained above, developing critical consciousness is a feature of Critical Cosmopolitan Theory; so is becoming cosmopolitan. The Greek etymological root (kosmopolitês) for cosmopolitan literally means citizen of the world. Appiah (2010) explains how being cosmopolitan means that one has a shared "value in human lives and humanity" (p. xv). Critical Cosmopolitan Theory depicts the development of global citizenship aligned to becoming critically conscious and humane. Guided by Critical Cosmopolitan Theory, our article examines four research questions:

1. What are teacher candidates' perceptions of investigating the world during their study abroad experiences? How do these perceptions compare?

2. What are teacher candidates' perceptions of recognizing perspectives during their study abroad experience? How do these perceptions compare?

3. What are teacher candidates' perceptions of communicating ideas during their study abroad experience? How do these perceptions compare?

4. What are teacher candidates' perceptions of being willing to take action because of their study abroad experience? How do these perceptions compare?

\section{Method}

We use comparative case study research design (Yin, 2017) to examine these aforementioned research questions. Comparative case study research design is more robust than singular case study design because of a deeper analysis within and between the cases (Yin, 2017). This paper compares 
two cases of teacher candidates' study abroad experiences; Table 1 provides a snapshot of the participants for each case study.

Table 1: Case study participants.

$$
\text { Case Study } 1 \quad \text { Case Study } 2
$$

\begin{tabular}{lll}
\hline Study abroad location & China & South Africa \\
\hline Pseudonym & East State University & Southmont University \\
\hline Participants & $\mathrm{n}=13$ teacher candidates & $\mathrm{n}=22$ teacher candidates \\
\hline Gender & $77 \%$ Female & $100 \%$ Female \\
& $23 \%$ Male & \\
\hline Demographics & $8 \%$ Black & $18 \%$ Black \\
& $92 \%$ White & $73 \%$ Latina \\
& & \\
\hline
\end{tabular}

\section{Context}

As Table 1 shows, Case Study 1 was a study abroad program in China. The program was 17 days long. Participants who attended this study abroad experience were all elementary education teacher candidates from East State University (a pseudonym), which is a regional research university located in the south-central region of the United States. The China study abroad program took place in the Beijing and Nanjing areas. Participants stayed at a host university and their experience included visits to different historical sites such as the Great Wall, the Forbidden City, the Summer Palace, and Tiananmen Square. The experiences also included 25 hours of observation and teaching at four schools, daily debrief sessions, and lectures from Chinese professors about Chinese culture and $\mathrm{K}-12$ education in China.

Case Study 2 was a study abroad program in South Africa. The program was 24 days long. Participants included 22 teaching candidates majoring in elementary education $(\mathrm{n}=20)$ or world languages $(n=2)$ at Southmont University (also a pseudonym), which is a large state university in the southeastern region of the United States. The South Africa study abroad experience primarily took place in the Cape Town area. The participants stayed at a host university. The participants' study abroad experience included over 40 hours of observation and teaching at four Cape Town area elementary schools. These public elementary schools were all different in terms of their Quintile standing within the South African education system (see Spaull, 2013). The South African government designates the schools as Quintile 2 and 3 public schools, meaning under-resourced schools, and a Quintile 5 school, which is a high resourced public school. The study abroad program included presentations by South African professors about the South African education system as well as an examination into the legacy of apartheid in the South African education system. The program included excursions to Robben Island and the District Six Museum in Cape Town. 


\section{Data Collection}

Data were collected after we gained human subject research permission from the University Institutional Review Board (IRB). We informed the participants of the study parameters and the study's reflection questions. All the participants gave their consent for the data collection. We did not analyze the data until after the study abroad program was finished and final grades were submitted. Our data collection included artifact analysis, participant interviews, and participant observation through field notes. The triangulation of data collection provided for a "thick description" (Geertz, 1973 , p. 3) about the study abroad settings and comparative findings between the two cases. In each case study, participants kept a reflective journal of their study abroad experiences. The journal included the following reflection prompts aligned with Critical Cosmopolitan Theory:

- Global citizens are aware and curious about the world and how it works. What are ways that you investigated the world during this study abroad program?

- Global citizens recognize that people may have different perspectives from their own. What new perspectives have you gained from this study abroad program?

- Global citizenship requires language and communication. What experiences have you had with cross-cultural communication during your study abroad program?

- Global citizens are action-oriented and ready to "re-write the world." Describe a time on this study abroad program where you observed someone making a difference and/or a time when you wanted to start taking action to make a difference.

Participant interviews further investigated the topics the teacher candidates wrote about while journaling. We conducted these interviews using a semi-structured interview approach (Holstein \& Gubrium, 1995).

\section{Data Analysis}

We analyzed the data qualitatively using Glaser and Strauss' (1967) constant-comparative method. We did this after the study abroad experiences were completed. We used pseudonyms to organize and report the findings. We first analyzed the data for each study abroad program separately. For this data analysis, we used Miles and Huberman's (1994) three-step interpretive process:

1. First, we read all the data from the artifacts, journals, and interview transcripts.

2. Second, we coded the data and organized these codes into larger categories.

3. Third, we analyzed these categories to identify similarities and differences in the data.

Then, we compared the findings from each of the study abroad programs. We use tables in the findings section to illustrate the comparisons. From this analysis of similarities and differences, we discuss the larger themes related to the development of global competencies among the two case study groups.

\section{Findings}

We found four larger themes from our data analysis. We report on each theme in relationship to the study's research questions. We organize the themes by the Asia Society's four global 
competencies: (1) investigating the world, (2) recognizing different perspectives, (3) communicating ideas, and (4) taking action.

\section{Investigating the World}

In both case studies, the participants reported how many experiences related to investigating the world as part of their study abroad experience. Much of these data focused on investigating via the examination of how culture and educational systems in China and South Africa differed from participants' experiences in the United States. Table 2 illustrates the comparisons among the two case study groups related to investigating the world.

Table 2: Comparative themes related to investigating the world.

Case Study $1 \quad$ Case Study 2

\begin{tabular}{lll}
\hline Study abroad location & China & South Africa \\
\hline Pseudonym & East State University & Southmont University \\
\hline Themes & Socio-cultural aspects of China & \\
\hline & Value of education in China & School resources \\
& Social life in China & Environmental awareness \\
& Environmental awareness & \\
\hline
\end{tabular}

Case study 1 .

The East State University participants focused their responses about investigating the world primarily on the socio-cultural aspects of China, as well as China's education system and emphasis on studying. For example, most of the East State University teacher candidates were interested in learning about aspects of Chinese culture, such as people, food, architecture, and environment. Teacher candidates constructed their own perspectives about this culture while they were observing the environment and interacting with Chinese people. They reported reflections in their journal and wrote about how they enjoyed most of the Chinese food they tried. They found the cultural representations in the architecture at the Forbidden City, the Temple of Heaven, and the Summer Palace quite fascinating. They also noticed that streets were very clean and air pollution was not as bad as reported in news when they were staying in Beijing.

Through their investigation of China, the East State University teacher candidates noticed the high value placed on education in China. One of the East State University participants, whom we call "Bob," shared in his reflection: "Students have a lot of pressure to perform well on tests in China. The parents in China seem to be highly involved and committed to their child's education." East State University participants, whom we call "Mary" and "Ellen," also commented on the importance of college entrance exams in China and recognized the substantial preparation for these exams among many of China's students. The East State University teacher candidates, however, questioned whether the emphasis on exams and constant testing was detrimental to Chinese students. The teacher candidates noticed similarities between China's system of higher education and the U.S. system. Here is how Mary explained the similarities: 
Prior to study abroad, I thought that classrooms in China would be drastically different and harder than classrooms in the United States. This thinking actually turned out to be false. From my observations I noticed that in many instances the classrooms were more similar between the two countries than they were different. The Chinese culture puts more emphasis on education, but the lecture style college classes had the same feel to the lecture style classes I have had in the United States.

The teacher candidates also made note of the differences in university life in China compared to the United States. In their journals, they wrote about how social life for Chinese college students was personal and noticed how many Chinese university students spent their weekend studying. One East State University teacher candidate, "Jeff," reflected on how this was "opposite to most American college students who go out on adventures and explore the city or party with friends." Finally, in their responses related to investigating China, the teacher candidates noticed that the Chinese were more environmentally cautious through water conservation and recycling. For example, Ellen wrote, "At home, we don't often think about how much electricity we are using, how much water we use, or turning off water in-between shampooing our hair. In China, they are much more environmentally cautious than in the United States." The teacher candidates wrote with conviction about the environmentalism in China and discussed how the United States could learn from conservation efforts in China.

Case study 2 .

As Table 2 shows, the Southmont University teacher candidates also wrote about environmental awareness and education in their journal entries. However, rather than emphasizing the value of education in South Africa, the Southmont University teacher candidates focused their responses on school resources. The teacher candidates wrote about the scarcity of teaching materials in the South African elementary schools. For example, one Southmont University teacher candidate, "Tasha," wrote, "I have noticed a lack of resources in some of the South African elementary schools. Before this study abroad, I didn't really think about not having access to resources like books and even a chalkboard in order to teach." The Southmont University teacher candidates reflected on the respect they had for the South African elementary school teachers who make do with the few resources they can scrounge up in order to teach. One participant, "Dee," discussed the South African teachers' ingenuity and provided the example of a teacher using bottle caps for counters in a math class. Another participant, "Madison," wrote about how a teacher snapped crayons in half so that all her students had crayons to use for coloring.

Investigating the world of the South African education system was also eye-opening for the Southmont University teacher candidates in terms of environmental education and conservation. The teacher candidates remarked on how many of the elementary schools did not have airconditioning and that school officials rarely turned on the heating system. They wrote about the open windows in the classroom, which allowed in fresh air. The school children arrived to school bundled up in jackets and removed them as the day heated up.

The teacher candidates also wrote about water conservation efforts in the schools. For instance, the Southmont teacher candidates remarked on the many signs and posters in schools, which provided visual reminders to turn off the tap when brushing teeth, take 90-second showers, and limit flushes of the toilet. Teacher candidates reflected on how they became more aware of their 
water usage and waste throughout their time in South Africa. These reminders helped the teacher candidates be, as Maria wrote, "more mindful and vigilant about their water usage." Like the East State University teacher candidates, the Southmont University candidates believed the United States has much to learn and put into practice in terms of environmental protection and water conservation.

\section{Recognizing Different Perspectives}

The issue of water conservation in both study abroad program settings (China and South Africa) reflects the emphasis on environmentalism, which is a different perspective than the teacher candidates in both case study groups may have had growing up in the United States. Indeed, the study abroad experience allowed both case study groups to develop deeper recognition of perspectives. Table 3 illustrates the comparative themes related to recognizing different perspectives.

Table 3: Comparative themes related to different recognizing perspectives.

Case Study 1

Study abroad location China

East State University

Case Study 2

South Africa

Pseudonym East State University Southmont University

Themes

Communist stereotypes

Uses of technology
Religious education

Socio-economic systems

Case study 1.

An East State University participant, "Barb," shared how most of her knowledge about China had come from communist stereotypes that she observed on television. Barb explained, "Upon arriving in China and throughout the trip I have gained a different perspective about the Chinese culture and what life is actually like in China." Technology shapes the ways teacher candidates learn about the world. Social media, Internet, TV shows, news, and movies were mentioned as influential on teacher candidates' perspectives on learning about different cultures. Mary described:

I believe technology is a heavy influence on how people perceive different cultures which creates a barrier for many people. A stereotype can be easily formed from the Internet. The stereotype can be about a certain race of people, which can prevent people from reaching out and being open to diversity. I believe this is a major cultural issue and this prevents many people from becoming culturally aware.

Teacher candidates also raised a concern regarding the Internet restriction policy in China. During their study abroad program, there were a number of blocked social media sites in China, including Facebook, Instagram, Twitter, Netflix, and Google. Teacher candidates considered this a problem as they were unable to access information about global issues. On the other hand, given limited restrictions on Internet use in the United States, the teacher candidates recognized the concern that 
a society may have about Internet safety among children and inappropriate materials being readily available.

Case study 2 .

While the East State University teacher candidates recognized different political perspectives during their study abroad to China, the Southmont University teacher candidates focused on religious education in the South African public schools. The Southmont University teachers taught in public elementary schools, which still have vestiges of a British education system, including religious education (RE). The RE time includes Morning Prayers, which was quite different for many of the teacher candidates. For example, one teacher candidate, "Jada," explained, "I found that I wasn't comfortable with the prayers during school. It seems like only one religion is catered to. I would like to find out more about why this is allowed in South African public schools." Madison also wrote about the inclusion of RE in schools, "The students have a prayer time in schools that they have to participate in. I don't agree with this because not all religions are being catered to during this time." The teacher candidates recognized a difference in perspectives about the religious observances in South African elementary schools compared to those in schools in the United States. They wrote about how it seemed like such RE catered mostly to Christianity while other religious beliefs were largely neglected.

Recognizing perspectives included the development of a larger, more global worldview. In their interviews, many of the teacher candidates explained how their worldview was narrow and focused mostly on the United States. The Southmont University teacher candidates further communicated a desire to have a greater perspective about the world and global events. Jada explained, "Participating in this study abroad has made me realize that I need to be more aware of what's happening not only in the United States, but in countries all over the world." Differences in socio-economic status, especially related to poverty, was one of the realizations that left an impression on the Southmont University teacher candidates. Dee wrote about having her eyes opened during a visit to a township. She explained, "Walking through the township made me aware of what poverty looks like and how families live together in a small space with very few resources." A local guide who grew up in the township led the township visit. The local guide had moved back to the township to start a nongovernmental organization (NGO) focused on after-school activities for the children living in the township. The guide explained how the visit was not going to be poverty tourism, but that rather the focus was on the community services, entrepreneurial spirit, and ingenuity within the township. The township visit fostered the teacher candidates' recognition of the legacies of apartheid, which persist in South Africa. A person can still see apartheid in the geography and in the divisions of labor. For example, it is more common to see a black South African as a housecleaner than a white South African. The recognition of perspectives also means reading the world to see the prevalence of social injustices that continue to manifest through racialized systems of inequality.

\section{Communicating Ideas}

The study abroad experiences afforded opportunities for cross-cultural communication and the recognition of the privileges that come with being speakers of English. Both case study groups recognized the challenges of communication, especially when there was no one to help translate languages. 
Table 4: Comparative themes related to communicating ideas.

\begin{tabular}{lll} 
& Case Study 1 & Case Study 2 \\
\hline Study abroad location & China & South Africa \\
\hline Pseudonym & East State University & Southmont University \\
\hline Themes & $\begin{array}{l}\text { Language translation challenges Use of visual } \\
\text { representations }\end{array}$ & $\begin{array}{l}\text { Multilingualism } \\
\text { Limitations of English }\end{array}$ \\
\hline
\end{tabular}

Case study 1 .

As Table 4 depicts, the East State University teacher candidates found it frustrating when there were no English translation of signs with Chinese characters. A number of them reported that the language barrier was challenging for them during the China study abroad program. The East State University teacher candidates found it difficult to communicate with others who were not fluent in English, especially when there was no one to help translate languages. They also found it frustrating when there was no English substitute for the Chinese written text. The East State University reported trying different modes of communication, such as gestures and pointing, and had a degree of success in exchanging information this way.

Another theme which emerged from this case study was how oral language is important but not always necessary for communication. Indeed, the teacher candidates explained how quickly they began to adopt and rely on universal signs for communication, such as facial expressions and body gestures. The teacher candidates also reported that some experiences like playing basketball required very little communication, because there is a "universal language" of sports, which almost everyone understands. Visual representations were also import to this theme. The candidates reported using visual representations to communicate especially when ordering food at restaurants. They would pick what they wanted from the pictures listed or order the same dishes they saw in another restaurant that they had tried and liked.

Case study 2.

Table 4 also illustrates how the themes the Southmont University teacher candidates identified related to the global competency of communicating ideas. The multilingualism of South African society was one of those themes. For example, many of the teacher candidates wrote about how impressed they were with the multilingualism of the South African elementary students. Most of the South African elementary school children were tri-lingual and could speak Afrikaans, English, and isiXhosa. The teacher candidates also reported how their study abroad experience made them more aware of their own privileges, especially as speakers of English. Madison put it this way, "I think I take too much for granted. I can only speak English, but I expect to just say 'hello' and people will understand me. This experience has opened my eyes to all the privileges that I have in terms of language." Dee wrote, "I have seen how English is used as a common way to communicate in South 
Africa and gives me access to the things I want to buy at the store. But, it doesn't give me full access to cultural understandings." These quotes by the Southmont University teacher candidates reflect how language is both a mode of communication and a point of access with another person. The English language provides a near-universal mode of communication in South Africa, but the English language does not guarantee access to or understanding of another person's history and cultural values.

\section{Taking Action}

The teacher candidates in both case study groups were ready to take action because of their study abroad experience. For this fourth theme, we report on the findings related to the teacher candidates' perspectives about how the study abroad trip compelled them to want to take action.

Table 5: Comparative themes related to taking action.

\begin{tabular}{lll}
\hline & Case Study 1 & Case Study 2 \\
\hline Study abroad location & China & South Africa \\
\hline Pseudonym & East State University & Southmont University \\
\hline Themes & $\begin{array}{l}\text { Promote study abroad } \\
\text { Classroom applications } \\
\text { Greater focus on the arts }\end{array}$ & $\begin{array}{l}\text { Adopt culturally responsive \& inclusive } \\
\text { teaching practices } \\
\text { Promote study abroad }\end{array}$ \\
\hline
\end{tabular}

Case study 1 .

As Table 5 illustrates, the East State University teacher candidates wanted to take action to encourage others to participate in study abroad. Among this group's case study data, participation was the most popular form of taking action, which included encouraging peers and their future students to gain study abroad and international experiences. For example, Mary wrote in her journal, "I will expose my future students to the world by encouraging travel, providing opportunities to attend different cultural events, and going on field trips to museums. I will share my study abroad experiences in order to reduce stereotypes." The East State teacher candidates also shared ways to take action related to cultural awareness and indicated that they would encourage their future students to explore different cultures to expand their global understanding.

The East State teacher candidates expressed the willingness to take action related to what they learned from the Chinese education system. They want to try and implement some of those strategies in their future teaching career. For example, Bob shared in his interview:

I did enjoy seeing different types of classrooms and the different styles of teaching. One of the aspects of the classroom I really thought was interesting was the monitor. The classroom monitor not only helped the teacher out, but it also gave the students an important role in the classroom that allows them to still interact and have a larger influence in the classroom. I think that I will carry a similar idea that follows the classroom monitor model. I want to assign my students different classroom jobs throughout the year so that way they can 
interact with the class in a different way and be able to learn about responsibility and to give the students a bigger role in the class.

Other East State University teacher candidates expressed how they wanted to take action by having a greater focus on the arts at a younger age. They were impressed with the Chinese education system's focus on the art of calligraphy, i.e., learning how to write the Chinese alphabet and text characters. Finally, the East State University teacher candidates were touched by the hospitality of the Chinese people. They explained how they wanted to invite their Chinese hosts to the United States and show them the same kind respect and kindness they had received.

Case study 2.

For the Southmont University teacher candidates, the most popular form of taking action was adopting culturally responsive pedagogies in their future teaching practice. They also planned to promote study abroad and international experiences. To enact culturally responsive instruction, the Southmont University teacher candidates wrote about the power of their study abroad experience to understand the importance of connecting with their students' cultural backgrounds. In her interview, Tasha shared how the life of Nelson Mandela inspired her to take action in terms of cultural responsiveness. She explained, "As a future teacher, I will be an advocate for my students and will also be purposeful about getting different cultures to interact in the classroom. Like Nelson Mandela, I want to be a teacher who brings people together." In her interview, Dee had this to share about cultural responsiveness: "During my time in South Africa, I taught many lessons on cultural awareness. I taught about the importance of knowing and respecting the culture of others. I will take these lessons back and teach them again in the US." For both of these Southmont University teacher candidates, cultural responsiveness was one of most powerful outcomes of taking action.

The Southmont University teacher candidates also connected taking action to the adoption of inclusive teaching practices. Inclusion is a philosophy of mainstreaming students with special needs in classrooms with general education students (Hembree, 2008). The purpose of inclusion is to provide supports for all students in the class-including students with disabilities. The reason for the teacher candidates' willingness to take action in this area seemed to relate to the lack of inclusion that they observed in the South African elementary school classrooms. Madison wrote about this in her journal as she observed the lack of attention to students with special needs. She wrote, "I plan on taking action on behalf of students with special needs. I felt that many of these students were just ignored. I will promote inclusive practices to make sure that students with special needs are part of the classroom." The commitment to inclusion was another example of how the Southmont University teacher candidates' eyes were opened during the study abroad experiences as they readied to take action.

Like the East State University teacher candidates, the Southmont University teacher candidates also planned to take action to promote the benefits of study abroad. For example, Dee explained how the study abroad opened her eyes to making a difference as a future teacher. She wrote about the difference she will make as a future teacher with these words, "I keep thinking about this quote that goes something like this: "People travel to faraway places to watch the kind of people they ignore at home.' I can no longer ignore the kids back home." Like Dee, the other Southmont University teacher candidates were excited to share their experiences with the children in their future classrooms. They also planned to promote study abroad to their peers in order to encourage them to 
attend future study abroad programs. As a group, the teacher candidates gained a deeper commitment to teaching in their future classrooms. Whether from East State University or Southmont University, the teacher candidates in both case studies communicated a greater resolve for the global competency of taking action as future educators.

\section{Discussion}

The teacher candidates in both case studies shared thoughts about the great impact of study abroad and international teaching experiences. The impact included the development of global competencies of investigating the world, recognizing different perspectives, communicating ideas, and taking action. The impact of study abroad was so profound that the teacher candidates in both case studies intended to promote study abroad programs upon their return to the United States. Our findings in this research confirm what Alfaro and Quezada (2010) assert about study abroad as a high impact practice for university students to gain international experience in teaching. The findings from these two case studies also confirm what researchers found about study abroad providing authentic experiences related to cultural responsiveness and developing a greater awareness for the host country's culture, language, and people (Alfaro \& Quezada, 2010; Byker, 2017, 2019; Byker \& Marquadt, 2016; Byker \& Putman, 2019; Pence \& Macgillivray, 2008). Furthermore, we found in these case studies that teacher candidates in both groups reported an increased interest in the study abroad country's politics, social norms, and traditions. Our findings also illustrated that student abroad experience not only develops the teacher candidates' global competencies but also prepares future educators as global citizens.

To explain, the two case studies illustrate how international teaching experiences expanded the teacher candidates' sense of agency-or the ability to take action-as future educators and citizens. The development of agency as global educators is an example of the many affordances of study abroad. In this current study, we found that study abroad was a catalyst for development of cosmopolitanism, which is the deeper connection to humanity (Appiah, 2010; Byker \& Banerjee, 2016). How did this happen? To address this question, we revisit Critical Cosmopolitan Theory (Byker, 2013), which is the theoretical framework for the case studies. Critical Cosmopolitan Theory defines and supports the development of critically conscious global competencies, which compels citizens to act in humane ways. We contend that the teacher candidates in the two case studies moved toward critical consciousness in four main ways. First, the teacher candidates in both case studies investigated the socio-cultural context of China and South Africa. They began reading the world (Byker, 2014; 2015; 2016; Freire, 1970) of China and South Africa even before the study abroad program commenced to understand the Chinese and South African context they would encounter. Second, the teacher candidates had their eyes opened to new perspectives about Chinese and South African cultural norms, educational pedagogies, language instruction, socio-economic status, and even the legacies of racist systems like apartheid. For many of the case studies' teacher candidates, the recognition of difference in perspectives included broadening their thinking about classroom sizes, instructional resources, and the language of instruction. Third, the case studies' teacher candidates developed a greater appreciation for multilingualism and the ability to communicate ideas in multiple languages. By the end of their study abroad programs, the teacher candidates valued language learning as a strength rather than a deficit. Related to the communication of ideas, both case studies' teacher candidates developed a greater commitment to communicating with students and families in culturally responsive ways. Fourth, the teacher candidates in both case 
studies developed a deeper commitment to taking action to make a difference as future educators. For some teacher candidates, taking action meant promoting the value of study abroad and international teaching opportunities with their colleagues. For others, taking action meant sharing their study abroad experiences in their future teaching classrooms back in the United States. As Byker (2016) asserts, rewriting the world is a form of taking action in the place where the person is embedded, but taking action also is deeply rooted in the question of why a person is compelled to rewrite the world. While our two case studies are in different contexts, the teacher candidates who participated in these case studies were inspired to take action because of how their study abroad experiences connected-and challenged-their notions of what it means to be an educator. The study abroad experience, whether in China or South Africa, helped the teacher candidates move toward critical consciousness as cosmopolitan citizens of the world.

\section{Limitations and Future Research}

There are limitations related to these comparative case studies of study abroad. The small sample sizes of both case studies is one limitation. The smaller numbers of students who can afford study abroad relates, in part, to the high program costs of international travel. Malewski and Phillion (2009) explain how a study abroad program's expensive price tag is cost prohibitive for many teacher candidates at public institutions. We recommend future research about addressing the access and affordability of study abroad programs. Additionally, we recommend that future research studies examine ways to localize international teaching experiences. By localize, we mean situating international teaching experiences in the places and locales of teacher education programs. For example, localizing international teaching experiences could include placing teacher candidates in a clinical experience that focuses on teaching English to children of refugees. A future research agenda would expand the sample size to include study abroad participants who are practicing teachers. Although there are not many study abroad opportunities for in-service teachers (yet), more research is needed about the types of programs that do exist, their costs, and their impact on classroom practice. Finally, a future research agenda would include longitudinal studies on study abroad programs in order to investigate the impact of international teaching experiences on the participants' classroom practices and identity as global educators.

\section{Conclusion}

Study abroad programs coupled with international teaching experiences encompass the possibilities of developing global educators who are also critically cosmopolitan citizens. Study abroad experiences make it possible for teacher candidates to develop global competencies through authentic learning opportunities in a context different than the United States. The case studies presented in our article highlight the possibilities of study abroad programs, whether in China, South Africa, or another country, in preparing teacher candidates to become critically conscious and cosmopolitan. In connection with these possibilities, this article illustrated the experiences of two sets of teacher candidates in developing global competencies through study abroad and international teaching experiences. In turn, the teacher candidates have committed to take action in order to share their international experiences and their global worldview with their future students. We believe that because of their study abroad experiences, the teacher candidates in these case studies are better equipped to guide their future students in reading and rewriting the world as global citizens. 


\section{References}

Appiah, K. A. (2010). Cosmopolitanism: Ethics in a world of strangers. New York, NY: WW Norton \& Company.

Alfaro, C., \& Quezada, R. (2010). International teacher professional development: Teacher reflections of authentic teaching and learning experiences. Teaching Education, 21, 47-59.

Bhattacharjea, S., \& Byker, E. J. (2017). The ASER "translating policy into practice" toolkit: From participatory action research to evidence-based action. In H. Kidwai, R. Iyengar, M. Witenstein, E. J. Byker, \& R. Setty (Eds.), Participatory action research and educational development: South Asian perspectives (pp. 75-96). New York, NY: Springer International Publishing.

Byker, E. J. (2013). Critical cosmopolitanism: Engaging students in global citizenship competencies. English in Texas Journal, 43(2), 18-22.

Byker, E. J. (2014). ICT oriented toward nyaya: Community computing in India's slums. International Journal of Education and Development using ICT, 10(2), 19-28.

Byker, E. J. (2015). Teaching for 'global telephony': A case study of a community school for India's 21st century. Policy Futures in Education, 13(2), 234-246.

Byker, E. J. (2016). Developing global citizenship consciousness: Case studies of critical cosmopolitan theory. Journal of Research in Curriculum and Instruction, 20(3), 264-275.

Byker, E. J. (2017). Reading and rewriting South Asia. In H. Kidwai, R. Iyengar, M. Witenstein, E. J. Byker, \& R. Setty (Eds.), Participatory action research and educational development: South Asian perspectives, (pp. 271-279). New York, NY: Springer International Publishing.

Byker, E. J. (2019). Study abroad as social and emotional learning: Framing international teaching with critical cosmopolitan theory. Journal of Research in Innovative Teaching \& Learning, 12(2), 183194. doi:10.1108/JRIT-02-2019-0023

Byker, E. J., \& Banerjee, A. (2016). Evidence for action: Translating field research into a large-scale assessment. Journal of Current Issues in Comparative Education, 18(1), 1-13.

Byker, E. J., \& Marquadt, S. (2016). Using critical cosmopolitanism to globally situate multicultural education in teacher preparation courses. Journal of Social Studies Education Research, 7(2), 30-50. Retrieved from http://jsser.org/article/view/5000203661/5000176548

Byker, E. J., Xu, T., \& Chen, J. (2016). Teacher quality in the twenty-first century: Developing globally competent teachers. In T. Petty, M. Putman, \& A. Good (Eds.), Handbook of research on professional development for quality teaching and learning. Hershey, PA: IGI Global. doi: 10.4018/978-1-5225-0204-3

Byker, E. J., \& Thomas, V. (2018). Culturally responsive webquests: Connecting technology with inquiry based learning. Teaching Social Studies Journal, 18(2), 19-25.

Byker, E. J., \& Putman, S. M. (2019). Catalyzing cultural and global competencies: Engaging preservice teachers in study abroad to expand the agency of citizenship. Journal of Studies in International Education, 23(1), 84-105. doi: 10.1177/1028315318814559

Byker, E. J., Putman, S. M., LeGrange, L. L., \& Reddy, C. (2019). Investigate for action: Preparing teacher candidates for Day Zero of the global water crisis. Kappa Delta Pi Record, 55(1), 4648. doi: 10.1080/00228958.2019.1549445

Council of Chief State School Officers [CCSSO]. (2016). Global preparation lens for the InTASC model core teaching standards. Washington, DC: NAFSA: Association of International Educators.

Cushner, K. (2007). The role of experience in the making of internationally-minded teachers. Teacher Education Quarterly, 34, 27-39.

Doppen, F. H. (2010). Overseas student teaching and national identity: Why go somewhere you feel completely comfortable? Journal of International Social Studies, 1(1), 3-18.

Freire, P. (1970). Pedagogy of the oppressed. New York, NY: Continuum.

Freire, P. (1994). Pedagogy of hope. New York, NY: Continuum.

Freire, P. (1998). Teachers as cultural workers. Boulder, CO: Westview Press.

Gay, G. (2002). Preparing for culturally responsive teaching. Journal of Teacher Education, 53, 106-116.

Geertz, C. (1973). The interpretation of cultures: Selected essays. New York, NY: Basic Books. 
Goodwin, A. L. (2010). Globalization and the preparation of quality teachers: Rethinking knowledge domains for teaching. Teaching Education, 21(1), 19-32.

Glaser, B. G., \& Strauss, A. L. (1967). The discovery of grounded theory: Strategies for qualitative research. Chicago, IL: Aldine.

Hammer, M. R., Bennett, M. J., \& Wiseman, R. (2003). Measuring intercultural sensitivity: The intercultural development inventory. International Journal of Intercultural Relations, 27, 421-443.

Hembree, D. (2008, November 21). The benefits of an inclusion classroom. Retrieved from: http://www.associatedcontent.com/article/1213203/the_benefits_of_an_inclusion_classroom.html?ca $\mathrm{t}=4$

Herrera, S. (2012). Globalization: Current constraints and promising perspectives. Journal of Curriculum and Instruction, 6(1), 1-10.

Intolubbe-Chmil, L., Spreen, C. A., \& Swap, R. J. (2012). Transformative learning: Participant perspectives on international experiential education. Journal of Research in International Education, $11(2), 165-180$.

Kandel, W. A. (2013). United States family-based immigration policy. Washington, DC: Congressional Research Service.

Kissock, C., \& Richardson, P. (2010). Calling for action within the teaching profession: It is time to internationalize teacher education. Teaching Education, 21, 89-101. doi:10.1080/10476210903467008

Longview Foundations. (2008). Teacher preparation for a global age. Washington, DC: Author.

Malewski, E., \& Phillion, J. (2009). International field experiences: The impact of class, gender and race on the perceptions and experiences of preservice teachers. Teaching and Teacher Education, 25(1), 52-60.

Mansilla, V. B., \& Jackson, A. (2011). Educating for global competency. New York, NY: Asia Society. Retrieved from_http://asiasociety.org/files/book-globalcompetence.pdf

Medina, A. L., Hathaway, J. I., \& Pilonieta, P. (2015). How preservice teachers' study abroad experiences lead to changes in their perceptions of English language learners. Frontiers: The Interdisciplinary Journal of Study Abroad, 25, 73-90.

Miles, M. B., \& Huberman, A. M. (1994). Qualitative data analysis (2nd ed.). Thousand Oaks, CA: Sage.

Paris, D. (2012). Culturally sustaining pedagogy: A needed change in stance, terminology, and practice. Educational Researcher, 41(3), 93-97.

Pence, H. M., \& Macgillivray, I. K. (2008). The impact of an international field experience on preservice teachers. Teaching and Teacher Education, 24, 14-25.

Pilonieta, P., Medina, A. L., \& Hathaway, J. I. (2017). The impact of a study abroad experience on preservice teachers' dispositions and plans for teaching English language learners. The Teacher Educator, 52(1), 22-38.

Rong, X. L., \& Preissle, J. (2009). Educating immigrant students in the 21 st century. Thousand Oaks, CA: Corwin Press.

Spaull, N. (2013). Poverty \& privilege: Primary school inequality in South Africa. International Journal of Educational Development, 33(5), 436-447.

Willard-Holt, C. (2001). The impact of a short-term international experience for preservice teachers. Teaching and Teacher Education, 17(4), 505-517.

Yin, R. (2017). Case study research and applications: Design and methods. Thousand Oaks, CA: Sage Publishing. 